\title{
A Provenance Maturity Model
}

\author{
Kerry Taylor ${ }^{1,2}$, Robert Woodcock ${ }^{3}$, Susan Cuddy ${ }^{4}$, \\ Peter Thew ${ }^{1}$, and David Lemon ${ }^{4}$ \\ 1 CSIRO Digital Productivity, Canberra, Australia \\ 2 Australian National University, Canberra, Australia \\ 3 CSIRO Mineral Resources, Canberra, Australia \\ 4 CSIRO Land and Water, Canberra, Australia \\ firstname.lastname@csiro.au
}

\begin{abstract}
The history of a piece of information is known as "provenance". From extensive interactions with hydro-and geo-scientists in Australian science agencies we found both widespread demand for provenance and widespread confusion about how to manage it and how to develop requirements for managing it.

We take inspiration from the well-known software development Capability Maturity Model to design a Maturity Model for provenance management that we call the PMM. The PMM can be used to assess the state of existing practices within an organisation or project, to benchmark practices and existing tools, to develop requirements for new provenance projects, and to track improvements in provenance management across an organisational unit.

We present the PMM and evaluate it through application in a workshop of scientists across three data-intensive science projects. We find that scientists recognise the value of a structured approach to requirements elicitation that ensures that aspects are not overlooked.
\end{abstract}

Keywords: provenance, reproducibility, lineage, pedigree, requirements.

\section{Introduction}

As the trend towards data-intensive cyberscience picks up pace, scientists are becoming increasingly concerned about data provenance. As consumers of data, scientists need to know: Where did this data come from? Is it good enough for me to use? Can I trust it? As producers of data and expert opinion, scientists need to ensure their results are scientifically credible, repeatable, and justified by the methods used and the reasoned interpretations made.

Knowledge of the history of a piece of information (where it came from, what it was generated for, and the workflow that generated it) is known as "provenance", although the terms "audit trail", "lineage" and "pedigree" are common synonyms. Understanding the provenance of a piece of information can be as important as the information itself. Using provenance, it should be possible to understand whether or not a piece of information is fit for the intended purpose or whether the information should be trusted. 
While these general concerns are quite widespread, implementing software systems for long-term provenance management needs much more thought about requirements for the business context, capture, representation and storage, retrieval, and usability. From extensive interactions with hydro-and geo-scientists in Australian science agencies we found widespread confusion around how to move from high level descriptions of outcomes towards statements of requirements for selection of tools and methods for implementation. This problem is magnified in multidisciplinary science projects.

In this paper a novel tool for developing requirements for provenance is presented, the Provenance Maturity Model (PMM). The PMM has been developed together with a method for provenance requirements elicitation that is not further discussed here. It has been specifically developed for a context of multiple, disconnected stakeholders who are generally unaware of the drivers, challenges and tradeoffs of provenance management, but it can be useful in any scenario where an implementation of provenance management is required, such as hydrological modelling [15], agricultural research [3], emergency management [13] and chemistry lab notebooks [2. The PMM can also be used to classify existing or aspirational tools and approaches to provenance to aid in tool selection after requirements are established.

Our development of the PMM was driven by our experience in the Bioregional Assessment program of the Australian Government; a program to understand the potential impacts of coal seam gas and large coal mining on water resources and water-related assets. It is a complex inter-governmental resource development decision-making process, with expectations of significant long term commercial and public interest in the decisions to be made. While there was very strong awareness of the necessity for provenance amongst the stakeholders, we struggled to discuss the breadth and depth of the impact of simple requirements statements. Elements of maturity have a major impact on the cost, distance from current practice, the ability to capture, and the ability to interoperate over organisational and disciplinary boundaries.

The content of the PMM was assembled by the authors' analysis of remarks and expectations of stakeholders in that and previous resource-exploitation scenarios. A survey of the research literature was also used to insert capabilities and maturity points that we may have missed. The PMM then provided a way to hold the conversations that were necessary to understand these issues where previously we had role, process and scope confusion. We needed the additional dimension of maturity to facilitate the conversation along with a context of costbenefit and risk.

\section{The PMM}

Like the Capability Maturity Model (CMM) [12, the PMM contains a matrix of capabilities described at five levels of maturity. The capabilities are grouped into Provenance Business, Data Management, Provenance Capture, Provenance Representation and Storage, Provenance Retrieval, and Usability. 
Table 1. PMM Capabilities(Rows)

\begin{tabular}{|c|c|}
\hline $\begin{array}{l}\text { PROVENANCE } \\
\text { NESS }\end{array}$ & $\begin{array}{l}\text { This category relates to the adoption and commitment } \\
\text { to provenance management. It also contains a grab bag } \\
\text { of issues that need to be addressed for any particular } \\
\text { provenance venture }\end{array}$ \\
\hline Longevity & How long are provenance records designed to be kept? \\
\hline Software maturity & $\begin{array}{l}\text { What is the maturity of the software being used; for ex- } \\
\text { ample does it have a known history of usage elsewhere or } \\
\text { is it unknown to the organisation? }\end{array}$ \\
\hline $\begin{array}{l}\text { Organizational awareness: } \\
\text { culture and behaviour }\end{array}$ & $\begin{array}{l}\text { Is there a culture that understands and appreciates } \\
\text { provenance? }\end{array}$ \\
\hline Value recognition & Does the organisation care about provenance? \\
\hline Governance & How formalised is the approach to provenance? \\
\hline Perspective & $\begin{array}{l}\text { The social extent of provenance sharing and inter- } \\
\text { pretability }\end{array}$ \\
\hline $\begin{array}{l}\text { Transaction costs: Produc- } \\
\text { tion vs. retrieval cost }\end{array}$ & $\begin{array}{l}\text { How to balance the cost of detailed record keeping versus } \\
\text { the cost of collection recording to provide an answer to a } \\
\text { query }\end{array}$ \\
\hline DATA MANAGEMENT & $\begin{array}{l}\text { This category of capabilities relates not so much to prove- } \\
\text { nance as to the management of the underlying data over } \\
\text { which provenance operates. It is included here because } \\
\text { certain features are necessary preconditions to prove- } \\
\text { nance maturity }\end{array}$ \\
\hline Data safety & $\begin{array}{l}\text { The resilience of data (that is the subject of provenance) } \\
\text { to failures in hardware and/or processing errors }\end{array}$ \\
\hline Data versioning & scheme to identify data versions? \\
\hline Data lineage & Is information kept to identify the source of data? \\
\hline Identifier Management & Is the underlying data unambiguously identified? \\
\hline Digital Preservation & $\begin{array}{l}\text { How well preserved are the digital artefacts that are the } \\
\text { subject of provenance? }\end{array}$ \\
\hline $\begin{array}{l}\text { PROVENANCE } \\
\text { TURE }\end{array}$ & $\begin{array}{l}\text { This category refers to the processes, methods and tools } \\
\text { for initial capture, or record-keeping, of provenance }\end{array}$ \\
\hline $\begin{array}{l}\text { Decision making and consul- } \\
\text { tation }\end{array}$ & $\begin{array}{l}\text { What records are kept on decisions made by people and } \\
\text { groups and how integrated are these records to a prove- } \\
\text { nance database? }\end{array}$ \\
\hline $\begin{array}{l}\text { Temporal scope (Start and } \\
\text { end points) }\end{array}$ & $\begin{array}{l}\text { In the scope of a process, when do we start capturing } \\
\text { provenance and when does it end? }\end{array}$ \\
\hline Granularity of capture & $\begin{array}{l}\text { The smallest unit of a process that generates a prove- } \\
\text { nance record - from a complete workflow down to indi- } \\
\text { vidual executables and commands }\end{array}$ \\
\hline Temporality/Currency & $\begin{array}{l}\text { When was the provenance record made with respect to } \\
\text { the execution of the process: during the process step-by- } \\
\text { step, at specific stages or after the fact? }\end{array}$ \\
\hline $\begin{array}{l}\text { Software tools used in pro- } \\
\text { cess }\end{array}$ & $\begin{array}{l}\text { What information is captured on software used within a } \\
\text { workflow \& the workflow system itself; for example ver- } \\
\text { sion number? }\end{array}$ \\
\hline
\end{tabular}


Table 1. (Continued)

\begin{tabular}{|c|c|}
\hline Hardware/platform & $\begin{array}{l}\text { Information on the hardware environment when a work- } \\
\text { flow is executed }\end{array}$ \\
\hline $\begin{array}{l}\text { Provenance capture integra- } \\
\text { tion }\end{array}$ & $\begin{array}{l}\text { How integrated is the collection of provenance records in } \\
\text { the process execution? For example does the carrying out } \\
\text { of the process generate provenance transparently or are } \\
\text { the provenance records obtained by post-processing log } \\
\text { files or independent data entry? }\end{array}$ \\
\hline Provenance quality & How trustworthy is the provenance record that is kept? \\
\hline \begin{tabular}{|l}
$\begin{array}{l}\text { Sophistication of automa- } \\
\text { tion }\end{array}$ \\
\end{tabular} & $\begin{array}{l}\text { How automated is the capture of provenance record; for } \\
\text { example manually or embedded into workflow processes }\end{array}$ \\
\hline $\begin{array}{|lr|}\text { PROVENANCE REPRE- } \\
\text { SENTATION \& STORAGE }\end{array}$ & $\begin{array}{l}\text { These capabilities discuss the static aspect of provenance } \\
\text { information; in between creating it and using it }\end{array}$ \\
\hline Provenance format & $\begin{array}{l}\text { Do the provenance records adhere to a standard, and } \\
\text { is that standard an international one or bespoke to the } \\
\text { organisation? }\end{array}$ \\
\hline Provenance language & $\begin{array}{l}\text { How formalised is the content of the provenance records; } \\
\text { for example free text or a strictly controlled language } \\
\text { (with specific meanings) }\end{array}$ \\
\hline Provenance security & $\begin{array}{l}\text { Can the provenance records be validated or can they be } \\
\text { corrupted or altered after collection; is there a way to } \\
\text { determine if corruption has occurred? }\end{array}$ \\
\hline $\begin{array}{l}\text { PROVENANCE } \\
\text { TRIEVAL }\end{array}$ & $\begin{array}{l}\text { These capabilities address the methods and support for } \\
\text { obtaining provenance information }\end{array}$ \\
\hline Provenance availability & $\begin{array}{l}\text { How easy it is for people (or systems) to access the prove- } \\
\text { nance records? }\end{array}$ \\
\hline Provenance discovery & $\begin{array}{l}\text { How easy is it to find the particular provenance record } \\
\text { they need? }\end{array}$ \\
\hline Licence to use provenance & $\begin{array}{l}\text { Are the conditions of use of the provenance itself well } \\
\text { understood? }\end{array}$ \\
\hline $\begin{array}{l}\text { PROVENANCE USABIL- } \\
\text { ITY }\end{array}$ & $\begin{array}{l}\text { These capabilities refer to how provenance can be, or is, } \\
\text { used: what is it all for? }\end{array}$ \\
\hline Human readable & $\begin{array}{l}\text { What attention is given to supporting the human inter- } \\
\text { pretation of the provenance record? }\end{array}$ \\
\hline Repeatable by automation & $\begin{array}{l}\text { Can a workflow be repeated using the provenance records } \\
\text { to identify all components and parameters that were used } \\
\text { in the original workflow? }\end{array}$ \\
\hline $\begin{array}{l}\text { Reusable, that is, repeatable } \\
\text { with improvement }\end{array}$ & $\begin{array}{l}\text { Can a workflow be repeated using the provenance records } \\
\text { but also allow deliberate substitutions; for example, an } \\
\text { updated model or new dataset? }\end{array}$ \\
\hline Transparent & $\begin{array}{l}\text { Can you see what judgement decisions were made, and } \\
\text { why? }\end{array}$ \\
\hline $\begin{array}{l}\text { Answerable (variation in re- } \\
\text { sults can be explained) }\end{array}$ & $\begin{array}{l}\text { Can the provenance records identify the component that } \\
\text { is the source of error or difference within a workflow with } \\
\text { respect to an alternative? }\end{array}$ \\
\hline $\begin{array}{l}\text { Cross-disciplinary } \\
\text { application }\end{array}$ & $\begin{array}{l}\text { Is everyone talking the same language? Are they being } \\
\text { forced inappropriately to talk the same language? }\end{array}$ \\
\hline
\end{tabular}


The five levels of maturity (columns) are labelled and described as follows where the original CMM title Repeatable has been replaced with Tactical to avoid conflicts with the use of that term in the study of provenance. The descriptions of each level have been modified to be more appropriate for provenance.

Initial(Chaotic). It is characteristic of provenance treatment at this level that

it is (typically) undocumented and in a state of dynamic change, tending to be driven in an ad hoc, uncontrolled and reactive manner by users or events. This provides a chaotic or unstable approach to provenance management and provenance services and certainly implies that any services developed will be of very low functionality and scope.

Tactical. It is characteristic of provenance treatment at this level that many aspects of data production and management are carried out with recordkeeping in mind. Some attention is being made to ensure that identified processes are repeatable in some circumstances, possibly with consistent results. Discipline is unlikely to be rigorous, but where it exists it may help to ensure that following an audit trail is possible under stress.

Defined. It is characteristic of provenance treatment at this level that there are sets of defined and documented standard processes established and routinely followed. These standard processes both require and enable standard tools to be developed and used. Such tools both assist in the implementation of the processes and offer provenance services to derive value from provenance across the organization or community.

Managed. It is characteristic of provenance treatment at this level that it has become uncontroversial: moved into the background as well-managed practices that are embedded in the fabric of business, travelling smoothly from project to project. It is consistently and effectively controlled and widely used.

Optimising. It is a characteristic of provenance management at this level that the focus is on continually improving performance of provenance management itself as a lever for continuous improvement of performance of the underlying scientific or administrative processes, through both incremental and innovative technological improvements. Provenance is a highly valued component of business delivering transparency, accountability and knowledge management.

The full PMM matrix of 33 capabilities by 5 maturity levels is included at the end of this paper.

\section{Evaluation}

The PMM was used for requirements elicitation for three projects of two government science agencies in August 2013, over a two-day workshop. Background material was provided, including the PMM evaluation of some existing tools, many of which were known to the participants, such as ISO-19115-LE [6] and Prov-O [7. The workshop included a half-day of presentations on the nature of 
provenance and some known tools and methods; brief presentations on the selected projects' goals; an introduction on the PMM and how to use it; a hands-on application of PMM to the three projects in project groups; a subsequent requirements documentation exercise; a plenary analysis of consequent requirements for the agency as a whole; and the joint development of an architecture sketch for the agency-wide provenance management. Those who were present for the full two days excluding the PMM developers and facilitators, that is 13 people, were surveyed at the beginning and again at the end of the workshop.

The survey participants were invited to respond to 21 questions of which 18 were phrased on a 5-level balanced Likert scale and all 21 included requests for free-text comments. In some cases participants indicated responses either in between or spanning consecutive levels; in all cases these have been treated as if the lowest (i.e. least positive) level was selected.

The lowest-scoring question overall was the pre-workshop question "Please rate your familiarity in dealing with issues or tools relating to provenance $(1=$ not all aware, 5=extremely aware)", for which the minimal response was 1 , the maximum 5, and the average 3.2. The highest-scoring question overall was the postworkshop "The approach to provenance management for your project will benefit by the application of the PMM as you have used it in the workshop (1=strongly disagree, $5=$ strongly agree)". The minimum response was 3 and the maximum was 5, with average 4.8. Other high-scoring questions referred to the contribution of the PMM towards developing user requirements. The lowest-scoring post-workshop question (average 3.7) referred to the ease of determining evaluation criteria, an element of the PMM application methodology that is out of scope for this paper. We can conclude that the participants found the PMM worthwhile.

The participants were also invited to suggest needs for clarification or other improvement to the PMM version that was used in the workshop. The PMM presented here has had some wording and sequencing adjustments since the workshop to take account of those suggestions.

\section{Related Work}

We have evaluated some existing tools and methods with respect to the PMM in order to provide some benchmarks to assist in interpretation of the PMM, and on the other hand, to assist project designers to locate tools that might help them achieve desired maturity levels. In this context, Prov-O [7] features due to its potential contribution towards high-maturity provenance Representation and Storage, therefore also contributing to high maturity Retrieval and Usability. Because of both its underlying flexible graph representation, and the ontology inference coupled with domain-specific ontology extensions, it is possible to use it to traverse widely differing domain-oriented provenance records through semantic, executable mappings to Prov-O, such as described in [3]. This can be done even when the primary record-keeping may be entirely ontology-unaware, such as is enabled by the mapping from ISO19115 Lineage to Prov-O [14. 
An alternative ISO19115-driven extension to Prov-O has been developed 9 that would be useful when an early commitment to Prov-O is made. We can envisage the particular utility of the Prov-O graph representation to support dynamic provenance assembly for federated information systems like [16], 1] and [17] that support retrieval of data products or query-answering over compositions of resources. In unpublished work, we are also exploiting the inference capability to support arbitrary provenance comparison, building on the graph matching of [8].

Recent work on provenance for an integrated ecosystem approach to management of large marine ecosystems [5] demonstrates a high level of maturity for Capture, whereby a Web application for the development of data products and charts, tables, and map visualisations also keeps track of steps taken then embeds the provenance in the final PDF report. The related Global Change Information system will demonstrate a high level of maturity for Data Management, particularly for identifier management over a heterogenous contributor community [10].

The notion of Research Objects [11, especially computational research objects 4], contributes to a very high level of maturity in Usability, with provenance records very closely tied to executable components for repeatability and reusability and also to the scientific practice.

\section{Conclusion}

We present the Provenance Maturity Model as a part of a structured approach to developing requirements for provenance management in data-intensive science. The PMM lays out many characteristics of provenance management in a matrix where preferred options may be considered and selected in the context of some evaluation criteria. We found that scientists recognise the value of a structured approach to requirements elicitation that ensures the depth and breadth of the issues are considered and that aspects are not overlooked. The value of the framework in clarifying the language in an "industry standard" approach is also appreciated.

We recommend using the PMM in a workshop environment once the scientific content of a project is well enough understood to commence. We recommend developing an evaluation criteria then proceeding to check cells in the PMM by consensus, adding additional rows if necessary. Later, system and software requirements can be developed in a conventional way, with frequent reference to the instantiated PMM. A record of tools and business processes that have previously been benchmarked by the PMM can help to fill in a solution architecture. Much later, the PMM can help to review provenance goals and to consider advancing the maturity.

In future work we would like to re-evaluate the PMM in an alternative cultural, organisational and problem context, and also to track the influence on project results through project life-cycle case studies.

Acknowledgement. The authors thank the anonymous reviewers and the many collaborators for their questions and insight, especially Neal Evans and Brian Hanisch of Geoscience Australia. 


\section{References}

1. Ackland, R., Taylor, K., Lefort, L., Cameron, M.A., Rahman, J.: Semantic Service Integration for Water Resource Management. In: Gil, Y., Motta, E., Benjamins, V.R., Musen, M.A. (eds.) ISWC 2005. LNCS, vol. 3729, pp. 816-828. Springer, Heidelberg (2005)

2. Adams, N., Haller, A., Krumpholz, A., Taylor, K.: A semantic lab notebookreport on a use case modelling an experiment of a microwave-based quarantine method. In: Linked Science (LISC 2013), vol. 1116, CEUR proceedings (October 2013)

3. Compton, M., Corsar, D., Taylor, K.: Sensor data provenance: SSNO and PROV-O together at last. To appear 7th International Semantic Sensor Networks Workshop (October 2014)

4. De Roure, D.: Towards computational research objects. In: Proceedings of the 1st International Workshop on Digital Preservation of Research Methods and Artefacts, DPRMA 2013, pp. 16-19. ACM, New York (2013)

5. Di Stefano, M., Fox, P., Beaulieu, S., Maffei, A., West, P., Hare, J.: Enabling the integrated assessment of large marine ecosystems: Informatics to the forefront of science-based decision support. In: AGU Fall Meeting, number Poster IN51A-1689, San Fancsisco, American GeoPhysical Union (December 2012)

6. ISO 19115-2:2009 geographic information - metadata - part 2: Extensions for imagery and gridded data. ISO19115-2 Standard (2009)

7. Lebo, T., Sahoo, S., McGuinness, D., Belhajjame, K., Cheney, J., Corsar, D., Garijo, D., Soiland-Reyes, S., Zednik, S., Zhao, J.: PROV-O: The PROV ontology. W3C Recommendation (2013), http://www.w3.org/TR/prov-o/ (accessed April 23, 2014)

8. Liu, Q., Zhao, X., Taylor, K., Lin, X., Squire, G., Kloppers, C., Miller, R.: Towards semantic comparison of multi-granularity process traces. Knowledge-Based Systems 52, 91-106 (2013)

9. Lopez, F.J., Barrera, J.: Linked map VGI provenance schema. Deliverable D1.6.1, Planet Data Network of Excellence (March 2014)

10. Ma, X., Fox, P., Tilmes, C., Jacobs, K., Waple, A.: Capturing provenance of global change information. Nature Climate Change 4(6), 409-413 (2014)

11. Page, K., Palma, R., Hołubowicz, P., Klyne, G., Soiland-Reyes, S., Cruickshank, D., Cabero, R.G., Cuesta, E.G., Roure, D.D., Zhao, J., Gómez-Pérez, J.M.: From workflows to research objects: An architecture for preserving the semantics of science. In: 2nd International Workshop on Linked Science 2012: Tackling Big Data (LISC2012), Boston, USA, vol. 951. CEUR Proceedings (November 2012)

12. Paulk, M.C., Curtis, B., Chrissis, M.B., Weber, C.V.: Capability maturity model, version 1.1. IEEE Software 10(4), 18-27 (1993)

13. Power, R., Wise, C., Robinson, B., Squire, G.: Harmonising web feeds for emergency management. In: Piantadosi, J., Anderssen, R.S., Boland, J. (eds.) MODSIM 2013, 20th International Congress on Modelling and Simulation, pp. 2194-2200. Modelling and Simulation Society of Australia and New Zealand (December 2013)

14. Shu, Y., Taylor, K.: ISO 19115 lineage ontology (January 2013) (accessed November 2013)

15. Shu, Y., Taylor, K., Hapuarachchi, P., Peters, C.: Modelling provenance in hydrologic science: A case study on streamflow forecasting. Journal of Hydroinformatics (2012) 
16. Taylor, K., Austin, T., Cameron, M.: Charging for information services in service-oriented architectures. In: Proceedings, International Workshop on Business Services Networks (BSN 2005), Workshop of IEEE International Conference on e-Technology,e-Commerce and e-Service, Kong Kong, pp. 112-119 (March 2005)

17. Woodcock, R., Simons, B., Duclaux, G., Cox, S.: AuScope's use of standards to deliver earth resource data. In: Geophysical Research Abstracts, volume 12:EGU2010-1556. European GeoPhysical Union General Assembly (2010) 
Table 2. The PMM capabilities $\times$ Maturity levels

Provenance Business This category relates to the adoption and commitment to provenance management. It also contains a grab bag of issues that need to be addressed for any particular provenance venture.

\begin{tabular}{|c|c|c|c|c|c|}
\hline Capability & $\begin{array}{l}\text { Initial } \\
\text { (Chaotic) }\end{array}$ & Tactical & Defined & Managed & Optimising \\
\hline Longevity & $\begin{array}{l}\text { No } \\
\text { provenance }\end{array}$ & $\begin{array}{l}\text { Lifetime of a } \\
\text { process } \\
\text { instance } \\
\text { execution }\end{array}$ & $\begin{array}{l}\text { Lifetime of } \\
\text { an identified } \\
\text { problem or } \\
\text { project to } \\
\text { which } \\
\text { knowledge is } \\
\text { being } \\
\text { applied }\end{array}$ & $\begin{array}{l}\text { Lifetime of a } \\
\text { consequent } \\
\text { action plan } \\
\text { or } \\
\text { agreement }\end{array}$ & $\begin{array}{l}\text { Deliberately } \\
\text { unbounded } \\
\text { without } \\
\text { prescription } \\
\text { in advance; } \\
\text { i.e. } \\
\text { evolutionary }\end{array}$ \\
\hline $\begin{array}{l}\text { Software } \\
\text { maturity }\end{array}$ & $\begin{array}{l}\text { Tools are } \\
\text { not aware of } \\
\text { provenance }\end{array}$ & $\begin{array}{l}\text { Experimental } \\
\text { developed }\end{array}$ & $\begin{array}{l}\text { Extensively } \\
\text { trialled }\end{array}$ & $\begin{array}{l}\text { Several } \\
\text { alternative } \\
\text { implementa- } \\
\text { tions } \\
\text { available, at } \\
\text { least some } \\
\text { are robust }\end{array}$ & $\begin{array}{l}\text { Appropriate } \\
\text { products are } \\
\text { available } \\
\text { and are also } \\
\text { supported } \\
\text { and } \\
\text { maintained }\end{array}$ \\
\hline $\begin{array}{l}\text { Organisationc } \\
\text { awareness: } \\
\text { culture and } \\
\text { behaviour }\end{array}$ & $\begin{array}{l}\text { No support } \\
\text { for } \\
\text { provenance }\end{array}$ & $\begin{array}{l}\text { Individual } \\
\text { or small } \\
\text { team } \\
\text { initiative }\end{array}$ & $\begin{array}{l}\text { Major or- } \\
\text { ganisational } \\
\text { support for } \\
\text { trial or } \\
\text { development } \\
\text { but lacking } \\
\text { maintenance } \\
\text { commitment }\end{array}$ & $\begin{array}{l}\text { Policy; Long } \\
\text { term } \\
\text { commitment } \\
\text { supported } \\
\text { by explicit } \\
\text { funding } \\
\text { stream }\end{array}$ & $\begin{array}{l}\text { Legislation } \\
\text { or } \\
\text { Regulation }\end{array}$ \\
\hline $\begin{array}{l}\text { Value } \\
\text { recognition }\end{array}$ & $\begin{array}{l}\text { No support } \\
\text { for } \\
\text { provenance }\end{array}$ & $\begin{array}{l}\text { Value of } \\
\text { provenance } \\
\text { is recognised } \\
\text { in the } \\
\text { custodian } \\
\text { (asset) }\end{array}$ & $\begin{array}{l}\text { Value of } \\
\text { provenance } \\
\text { is exploited } \\
\text { opportunis- } \\
\text { tically }\end{array}$ & $\begin{array}{l}\text { Provenance } \\
\text { value } \\
\text { exploitation } \\
\text { is intrinsic } \\
\text { part of } \\
\text { business } \\
\text { model }\end{array}$ & $\begin{array}{l}\text { Provenance } \\
\text { is recognised } \\
\text { as a } \\
\text { knowledge } \\
\text { base of } \\
\text { evolving } \\
\text { scientific } \\
\text { method and } \\
\text { used for } \\
\text { continuous } \\
\text { improve- } \\
\text { ment } \\
\text { processes }\end{array}$ \\
\hline
\end{tabular}




\begin{tabular}{|c|c|c|c|c|c|}
\hline Capability & $\begin{array}{l}\text { Initial } \\
\text { (Chaotic) }\end{array}$ & Tactical & Defined & Managed & Optimising \\
\hline Governance & $\begin{array}{l}\text { No support } \\
\text { for } \\
\text { provenance }\end{array}$ & $\begin{array}{l}\text { Implicit } \\
\text { (everybody } \\
\text { knows it, } \\
\text { but it is not } \\
\text { formally } \\
\text { captured) }\end{array}$ & $\begin{array}{l}\text { Explicit. } \\
\text { Written, } \\
\text { formal, } \\
\text { contractual } \\
\text { management }\end{array}$ & $\begin{array}{l}\text { Provenance } \\
\text { record } \\
\text { management } \\
\text { plans are } \\
\text { comprehen- } \\
\text { sive and } \\
\text { followed }\end{array}$ & $\begin{array}{l}\text { Formal ac- } \\
\text { countability } \\
\text { and } \\
\text { governance } \\
\text { throughout } \\
\text { lifecycle } \\
\text { established } \\
\text { with \& } \\
\text { between } \\
\text { parties }\end{array}$ \\
\hline Perspective & $\begin{array}{l}\text { No support } \\
\text { for } \\
\text { provenance }\end{array}$ & $\begin{array}{l}\text { Individual: I } \\
\text { know what I } \\
\text { did }\end{array}$ & $\begin{array}{l}\text { Team: We } \\
\text { know what } \\
\text { we did }\end{array}$ & $\begin{array}{l}\text { Organisation: } \\
\text { we know } \\
\text { what our } \\
\text { teams did }\end{array}$ & $\begin{array}{l}\text { Community: } \\
\text { we all know } \\
\text { what } \\
\text { everyone did }\end{array}$ \\
\hline $\begin{array}{l}\text { Transaction } \\
\text { costs: } \\
\text { Production } \\
\text { vs. retrieval } \\
\text { cost }\end{array}$ & $\begin{array}{l}\text { No support } \\
\text { for } \\
\text { provenance }\end{array}$ & $\begin{array}{l}\text { Low cost of } \\
\text { production } \\
\text { but retrieval } \\
\text { is very } \\
\text { expensive } \\
\text { and slow } \\
\text { and not } \\
\text { always } \\
\text { possible }\end{array}$ & $\begin{array}{l}\text { Trade-off } \\
\text { recognised } \\
\text { and accom- } \\
\text { modated in } \\
\text { many cases }\end{array}$ & $\begin{array}{l}\text { Incremental } \\
\text { cost of } \\
\text { retrieval } \\
\text { close to zero } \\
\text { where } \\
\text { justified }\end{array}$ & $\begin{array}{l}\text { Identified } \\
\text { cost / } \\
\text { benefit } \\
\text { habitually } \\
\text { used in } \\
\text { design } \\
\text { decisions }\end{array}$ \\
\hline
\end{tabular}

Data Management This category of capabilities relates not so much to provenance as to the management of the underlying data over which provenance operates. It is included here because certain features are necessary preconditions to provenance maturity

\begin{tabular}{|c|c|c|c|c|c|}
\hline Capability & $\begin{array}{l}\text { Initial } \\
\text { (Chaotic) }\end{array}$ & Tactical & Defined & Managed & Optimising \\
\hline Data safety & No backups & $\begin{array}{l}\text { Data is } \\
\text { manually } \\
\text { backed up }\end{array}$ & $\begin{array}{l}\text { Data backup } \\
\text { is part of an } \\
\text { automated } \\
\text { backup } \\
\text { process }\end{array}$ & $\begin{array}{l}\text { Data } \\
\text { backups are } \\
\text { stored } \\
\text { off-site }\end{array}$ & $\begin{array}{l}\text { Data } \\
\text { backups } \\
\text { undergo } \\
\text { regular } \\
\text { restore tests }\end{array}$ \\
\hline
\end{tabular}




\begin{tabular}{|c|c|c|c|c|c|}
\hline Capability & $\begin{array}{l}\text { Initial } \\
\text { (Chaotic) }\end{array}$ & Tactical & Defined & Managed & Optimising \\
\hline $\begin{array}{l}\text { Data } \\
\text { versioning }\end{array}$ & $\begin{array}{l}\text { Unknown } \\
\text { versions }\end{array}$ & $\begin{array}{l}\text { Old data } \\
\text { replaced by } \\
\text { new data. } \\
\text { Version } \\
\text { identifica- } \\
\text { tion } \\
\text { associated } \\
\text { with new } \\
\text { data }\end{array}$ & $\begin{array}{l}\text { Old data is } \\
\text { archived and } \\
\text { associated } \\
\text { with version } \\
\text { identifica- } \\
\text { tion. }\end{array}$ & $\begin{array}{l}\text { Version } \\
\text { control of } \\
\text { collections }\end{array}$ & $\begin{array}{l}\text { Data } \\
\text { elements } \\
\text { (e.g } \\
\text { database } \\
\text { tuples) } \\
\text { dated and } \\
\text { annotated } \\
\text { with } \\
\text { provenance }\end{array}$ \\
\hline $\begin{array}{l}\text { Data } \\
\text { licensing }\end{array}$ & Unknown & $\begin{array}{l}\text { Licence } \\
\text { conditions } \\
\text { are } \\
\text { recorded, or } \\
\text { a system } \\
\text { wide } \\
\text { standard } \\
\text { licence } \\
\text { applies }\end{array}$ & $\begin{array}{l}\text { Licence need } \\
\text { not be } \\
\text { system-wide } \\
\text { and } \\
\text { conditions } \\
\text { are } \\
\text { retrievable } \\
\text { from point } \\
\text { of access to } \\
\text { data }\end{array}$ & $\begin{array}{l}\text { Licence need } \\
\text { not be } \\
\text { system-wide } \\
\text { and } \\
\text { conditions } \\
\text { are } \\
\text { retrievable } \\
\text { from point } \\
\text { of access to } \\
\text { data }\end{array}$ & $\begin{array}{l}\text { Flexible } \\
\text { licencing } \\
\text { policies can } \\
\text { be expressed } \\
\text { and compu- } \\
\text { tationally } \\
\text { validated in } \\
\text { the context } \\
\text { of the } \\
\text { intended use } \\
\text { of the data }\end{array}$ \\
\hline $\begin{array}{l}\text { Identifier } \\
\text { Manage- } \\
\text { ment }\end{array}$ & None & $\begin{array}{l}\text { Locally- } \\
\text { scoped } \\
\text { identifiers } \\
\text { are assigned, } \\
\text { possibly } \\
\text { through a } \\
\text { file-naming } \\
\text { convention }\end{array}$ & $\begin{array}{l}\text { Systematic, } \\
\text { unique } \\
\text { identifier } \\
\text { assignment, } \\
\text { crossing } \\
\text { datatypes } \\
\text { and } \\
\text { technology } \\
\text { platforms, } \\
\text { supporting } \\
\text { retrieval of } \\
\text { identified } \\
\text { objects }\end{array}$ & $\begin{array}{l}\text { Systematic, } \\
\text { globally } \\
\text { unique and } \\
\text { resolvable } \\
\text { identifier } \\
\text { management }\end{array}$ & $\begin{array}{l}\text { International } \\
\text { standards } \\
\text { followed; } \\
\text { resolvable } \\
\text { identifiers } \\
\text { maintained } \\
\text { over time }\end{array}$ \\
\hline $\begin{array}{l}\text { Digital } \\
\text { preservation }\end{array}$ & None & $\begin{array}{l}\text { Some } \\
\text { project } \\
\text { materials } \\
\text { and output } \\
\text { data are } \\
\text { archived }\end{array}$ & $\begin{array}{l}\text { Systematic } \\
\text { data } \\
\text { preservation } \\
\text { mechanisms } \\
\text { are in place } \\
\text { for identified } \\
\text { strategic } \\
\text { data }\end{array}$ & $\begin{array}{l}\text { Digital } \\
\text { preservation } \\
\text { strategies } \\
\text { extend to } \\
\text { digital } \\
\text { artefacts } \\
\text { such as } \\
\text { software and } \\
\text { minuted } \\
\text { decisions }\end{array}$ & $\begin{array}{l}\text { Digital } \\
\text { preservation } \\
\text { strategies } \\
\text { follow } \\
\text { international } \\
\text { standards } \\
\text { and are } \\
\text { regularly } \\
\text { reviewed for } \\
\text { scope, best } \\
\text { practice, } \\
\text { and } \\
\text { longevity }\end{array}$ \\
\hline
\end{tabular}


Provenance Capture This category refers to the processes, methods and tools for initial capture, or record-keeping, of provenance

\begin{tabular}{|c|c|c|c|c|c|}
\hline Capability & $\begin{array}{l}\text { Initial } \\
\text { (Chaotic) }\end{array}$ & Tactical & Defined & Managed & Optimising \\
\hline $\begin{array}{l}\text { Decision } \\
\text { making and } \\
\text { consultation }\end{array}$ & No records & $\begin{array}{l}\text { Decision- } \\
\text { taking } \\
\text { meetings } \\
\text { and } \\
\text { individual } \\
\text { choices in } \\
\text { process are } \\
\text { documented } \\
\text { and justified }\end{array}$ & $\begin{array}{l}\text { Documentatic } \\
\text { retrievable } \\
\text { from } \\
\text { multiple } \\
\text { access points }\end{array}$ & $\begin{array}{l}\text { Judgement } \\
\text { choices are } \\
\text { entirely } \\
\text { transparent } \\
\text { and fully } \\
\text { integrated } \\
\text { into } \\
\text { provenance } \\
\text { record and } \\
\text { services }\end{array}$ & $\begin{array}{l}\text { Reasoning } \\
\text { services } \\
\text { incorporated } \\
\text { e.g. to } \\
\text { identify } \\
\text { decisions } \\
\text { that follow } \\
\text { policy (or } \\
\text { not) }\end{array}$ \\
\hline $\begin{array}{l}\text { Temporal } \\
\text { scope (Start } \\
\text { and end } \\
\text { points) }\end{array}$ & $\begin{array}{l}\text { No } \\
\text { provenance }\end{array}$ & $\begin{array}{l}\text { Case-by- } \\
\text { case; driven } \\
\text { by other } \\
\text { procedural } \\
\text { concerns }\end{array}$ & $\begin{array}{l}\text { Defined and } \\
\text { applied at } \\
\text { project level } \\
\text { with end } \\
\text { purposes in } \\
\text { mind }\end{array}$ & $\begin{array}{l}\text { System-wide } \\
\text { principles } \\
\text { for } \\
\text { provenance } \\
\text { established } \\
\text { that } \\
\text { determine } \\
\text { scope }\end{array}$ & $\begin{array}{l}\text { Generally } \\
\text { lifecycle- } \\
\text { complete, } \\
\text { but entirely } \\
\text { adaptable to } \\
\text { cases } \\
\text { without loss } \\
\text { of verity }\end{array}$ \\
\hline $\begin{array}{l}\text { Granularity } \\
\text { of capture }\end{array}$ & Undetermine & $\begin{array}{l}\text { Coarse } \\
\text { grained. } \\
\text { Resources } \\
\text { and } \\
\text { methods are } \\
\text { loosely } \\
\text { described }\end{array}$ & $\begin{array}{l}\text { High-level } \\
\text { components } \\
\text { captured } \\
\text { but not all } \\
\text { well } \\
\text { described in } \\
\text { terms of role } \\
\text { or properties }\end{array}$ & $\begin{array}{l}\text { Low-level } \\
\text { components } \\
\text { captured } \\
\text { from the } \\
\text { point of } \\
\text { view of } \\
\text { decisions } \\
\text { made, steps } \\
\text { taken, tools } \\
\text { and data } \\
\text { used }\end{array}$ & $\begin{array}{l}\text { Granularity } \\
\text { of capture is } \\
\text { driven by } \\
\text { understand- } \\
\text { ing of future } \\
\text { require- } \\
\text { ments }\end{array}$ \\
\hline $\begin{array}{l}\text { Temporality } \\
\text { / Currency }\end{array}$ & $\begin{array}{l}\text { Provenance } \\
\text { not captured }\end{array}$ & $\begin{array}{l}\text { Reconstructer } \\
\text { on demand, } \\
\text { after the } \\
\text { fact }\end{array}$ & $\begin{array}{l}\text { Constructed } \\
\text { on demand } \\
\text { from con- } \\
\text { temporary } \\
\text { notes }\end{array}$ & $\begin{array}{l}\text { Real time } \\
\text { production } \\
\text { but decaying } \\
\text { record }\end{array}$ & $\begin{array}{l}\text { Designed for } \\
\text { long term } \\
\text { storage and } \\
\text { interpreta- } \\
\text { tion }\end{array}$ \\
\hline $\begin{array}{l}\text { Software } \\
\text { tools used in } \\
\text { process }\end{array}$ & Untraceable & $\begin{array}{l}\text { Identified by } \\
\text { commonly } \\
\text { understood } \\
\text { monikers }\end{array}$ & $\begin{array}{l}\text { Versions, } \\
\text { dates and } \\
\text { providers } \\
\text { rigorously } \\
\text { identified }\end{array}$ & $\begin{array}{l}\text { Originals } \\
\text { archived } \\
\text { with } \\
\text { descriptions, } \\
\text { including } \\
\text { metadata }\end{array}$ & $\begin{array}{l}\text { Fully } \\
\text { integrated } \\
\text { into } \\
\text { provenance } \\
\text { services }\end{array}$ \\
\hline
\end{tabular}




\begin{tabular}{|c|c|c|c|c|c|}
\hline Capability & $\begin{array}{l}\text { Initial } \\
\text { (Chaotic) }\end{array}$ & Tactical & Defined & Managed & Optimising \\
\hline $\begin{array}{l}\text { Hardware / } \\
\text { platform }\end{array}$ & Untraceable & $\begin{array}{l}\text { Identified by } \\
\text { commonly } \\
\text { understood } \\
\text { monikers }\end{array}$ & $\begin{array}{l}\text { Versions, } \\
\text { dates and } \\
\text { providers } \\
\text { rigorously } \\
\text { identified }\end{array}$ & $\begin{array}{l}\text { Originals } \\
\text { archived } \\
\text { with } \\
\text { descriptions, } \\
\text { including } \\
\text { metadata }\end{array}$ & $\begin{array}{l}\text { Fully } \\
\text { integrated } \\
\text { into } \\
\text { provenance } \\
\text { services }\end{array}$ \\
\hline $\begin{array}{l}\text { Provenance } \\
\text { capture } \\
\text { integration }\end{array}$ & $\begin{array}{l}\text { No } \\
\text { integration }\end{array}$ & $\begin{array}{l}\text { Provenance } \\
\text { is created by } \\
\text { separate } \\
\text { processes, } \\
\text { usually } \\
\text { running in } \\
\text { parallel to } \\
\text { workflows }\end{array}$ & $\begin{array}{l}\text { Integration } \\
\text { into tools } \\
\text { and } \\
\text { workflows }\end{array}$ & $\begin{array}{l}\text { Standards } \\
\text { based } \\
\text { capture } \\
\text { from tools } \\
\text { and } \\
\text { workflows }\end{array}$ & $\begin{array}{l}\text { Plug and } \\
\text { play with } \\
\text { whatever is } \\
\text { needed, } \\
\text { tracking } \\
\text { provenance }\end{array}$ \\
\hline $\begin{array}{l}\text { Provenance } \\
\text { quality }\end{array}$ & Unknown & $\begin{array}{l}\text { Unreliable } \\
\text { or partial; } \\
\text { user } \\
\text { feedback } \\
\text { collected } \\
\text { and } \\
\text { published }\end{array}$ & $\begin{array}{l}\text { Measured } \\
\text { occasionally; } \\
\text { quality may } \\
\text { be inferred } \\
\text { from other } \\
\text { attributes } \\
\text { such as } \\
\text { author, date }\end{array}$ & $\begin{array}{l}\text { Measured } \\
\text { routinely, } \\
\text { quality } \\
\text { limits and } \\
\text { impact are } \\
\text { understood }\end{array}$ & $\begin{array}{l}\text { Effective } \\
\text { methods to } \\
\text { detect and } \\
\text { improve bad } \\
\text { provenance } \\
\text { in place. All } \\
\text { provenance } \\
\text { is } \\
\text { trustworthy; } \\
\text { or trustwor- } \\
\text { thiness is } \\
\text { well } \\
\text { documented }\end{array}$ \\
\hline $\begin{array}{l}\text { Sophisticatior } \\
\text { of } \\
\text { automation }\end{array}$ & $\begin{array}{l}\text { None / } \\
\text { manual }\end{array}$ & $\begin{array}{l}\text { Policies for } \\
\text { collection } \\
\text { are } \\
\text { established } \\
\text { and followed } \\
\text { but interpre- } \\
\text { tations are } \\
\text { localised }\end{array}$ & $\begin{array}{l}\text { Habitual } \\
\text { recording in } \\
\text { a systematic } \\
\text { (e.g. } \\
\text { tablular) } \\
\text { way in } \\
\text { identifiable } \\
\text { documents } \\
\text { that are sys- } \\
\text { tematically } \\
\text { archived and } \\
\text { validated }\end{array}$ & $\begin{array}{l}\text { Capture is } \\
\text { embedded in } \\
\text { data- and } \\
\text { decision- } \\
\text { processing } \\
\text { software; } \\
\text { some } \\
\text { aspects } \\
\text { demanding } \\
\text { operator } \\
\text { input }\end{array}$ & $\begin{array}{l}\text { Integrated } \\
\text { into the } \\
\text { culture and } \\
\text { toolsets }\end{array}$ \\
\hline
\end{tabular}


Provenance Representation \& Storage These capabilities discuss the static aspect of provenance information; in between creating it and using it

\begin{tabular}{|c|c|c|c|c|c|}
\hline Capability & $\begin{array}{l}\text { Initial } \\
\text { (Chaotic) }\end{array}$ & Tactical & Defined & Managed & Optimising \\
\hline $\begin{array}{l}\text { Provenance } \\
\text { format }\end{array}$ & $\begin{array}{l}\text { No } \\
\text { provenance }\end{array}$ & $\begin{array}{l}\text { Provenance } \\
\text { may be } \\
\text { mentioned } \\
\text { in key } \\
\text { papers; } \\
\text { simple } \\
\text { schemes like } \\
\text { filename } \\
\text { conventions } \\
\text { and time } \\
\text { stamps may } \\
\text { be used }\end{array}$ & $\begin{array}{l}\text { Formal } \\
\text { standard for } \\
\text { provenance } \\
\text { format } \\
\text { adopted and } \\
\text { practised at } \\
\text { key places }\end{array}$ & $\begin{array}{l}\text { Flexible } \\
\text { standard or } \\
\text { tool- } \\
\text { dependent } \\
\text { formats } \\
\text { prescribed } \\
\text { and followed } \\
\text { according to } \\
\text { minimal } \\
\text { capture } \\
\text { granularity }\end{array}$ & $\begin{array}{l}\text { Interoperable } \\
\text { mappings } \\
\text { over } \\
\text { multiple } \\
\text { formats im- } \\
\text { plemented; } \\
\text { may rely on } \\
\text { overarching } \\
\text { standard }\end{array}$ \\
\hline $\begin{array}{l}\text { Provenance } \\
\text { language }\end{array}$ & None & $\begin{array}{l}\text { Interpretatior } \\
\text { relies on } \\
\text { natural } \\
\text { language } \\
\text { methods }\end{array}$ & $\begin{array}{l}\text { Information } \\
\text { is captured } \\
\text { by link to } \\
\text { controlled } \\
\text { vocabulary } \\
\text { with } \\
\text { glossary }\end{array}$ & $\begin{array}{l}\text { Semantics is } \\
\text { captured by } \\
\text { link to a } \\
\text { formal } \\
\text { ontology }\end{array}$ & $\begin{array}{l}\text { Representation } \\
\text { are } \\
\text { interpreted } \\
\text { for interop- } \\
\text { erability and } \\
\text { adaptation } \\
\text { to context of } \\
\text { use }\end{array}$ \\
\hline $\begin{array}{l}\text { Provenance } \\
\text { security }\end{array}$ & None & $\begin{array}{l}\text { Original } \\
\text { provider of } \\
\text { provenance } \\
\text { identifiable }\end{array}$ & $\begin{array}{l}\text { Formal } \\
\text { processes for } \\
\text { authentica- } \\
\text { tion and } \\
\text { audit trail }\end{array}$ & $\begin{array}{l}\text { Provenance } \\
\text { is signed } \\
\text { and tamper- } \\
\text { proof, } \\
\text { within an } \\
\text { organisation } \\
\text { on selected } \\
\text { transactions }\end{array}$ & $\begin{array}{l}\text { Non- } \\
\text { repudiation }\end{array}$ \\
\hline
\end{tabular}


Provenance Retrieval These capabilities address the methods and support for obtaining provenance information.

\begin{tabular}{|c|c|c|c|c|c|}
\hline Capability & $\begin{array}{l}\text { Initial } \\
\text { (Chaotic) }\end{array}$ & Tactical & Defined & Managed & Optimising \\
\hline $\begin{array}{l}\text { Provenance } \\
\text { availability }\end{array}$ & Clueless & $\begin{array}{l}\text { Non- } \\
\text { automated; } \\
\text { requires } \\
\text { judgement }\end{array}$ & $\begin{array}{l}\text { Database or } \\
\text { web page }\end{array}$ & Web Service & $\begin{array}{l}\text { Direct } \\
\text { availability } \\
\text { to analysis } \\
\text { and } \\
\text { reporting } \\
\text { tools; API } \\
\text { supporting } \\
\text { structured } \\
\text { queries }\end{array}$ \\
\hline $\begin{array}{l}\text { Provenance } \\
\text { discovery }\end{array}$ & $\begin{array}{l}\text { "Phone a } \\
\text { friend" }\end{array}$ & $\begin{array}{l}\text { Retrievable } \\
\text { from point } \\
\text { of data } \\
\text { product } \\
\text { identifica- } \\
\text { tion }\end{array}$ & $\begin{array}{l}\text { Full text } \\
\text { search over } \\
\text { provenance } \\
\text { records-can } \\
\text { retrieve cor- } \\
\text { responding } \\
\text { data } \\
\text { through } \\
\text { provenance } \\
\text { search }\end{array}$ & $\begin{array}{l}\text { Search by } \\
\text { provenance } \\
\text { structure } \\
\text { and } \\
\text { components: } \\
\text { can retrieve } \\
\text { correspond- } \\
\text { ing } \\
\text { data }\end{array}$ & $\begin{array}{l}\text { Search for } \\
\text { provenance } \\
\text { patterns: } \\
\text { can analyse } \\
\text { provenance } \\
\text { itself as } \\
\text { subject of } \\
\text { enquiry }\end{array}$ \\
\hline $\begin{array}{l}\text { Licence to } \\
\text { use } \\
\text { provenance }\end{array}$ & Unknown & $\begin{array}{l}\text { Licence } \\
\text { conditions } \\
\text { are recorded } \\
\text { or a } \\
\text { system-wide } \\
\text { standard } \\
\text { licence } \\
\text { applies }\end{array}$ & $\begin{array}{l}\text { Licence need } \\
\text { not be } \\
\text { system-wide } \\
\text { and special } \\
\text { conditions } \\
\text { are } \\
\text { retrievable } \\
\text { from point } \\
\text { of access to } \\
\text { provenance }\end{array}$ & $\begin{array}{l}\text { Privacy or } \\
\text { confidential- } \\
\text { ity } \\
\text { conditions } \\
\text { on access to } \\
\text { provenance } \\
\text { are enforced } \\
\text { by tools }\end{array}$ & $\begin{array}{l}\text { Flexible } \\
\text { licencing } \\
\text { policies can } \\
\text { be expressed } \\
\text { and } \\
\text { validated } \\
\text { computa- } \\
\text { tionally at } \\
\text { the point of } \\
\text { access to } \\
\text { provenance }\end{array}$ \\
\hline
\end{tabular}


Provenance Usability These capabilities refer to how provenance can be, or is, used: what is it all for?

\begin{tabular}{|c|c|c|c|c|c|}
\hline Capability & $\begin{array}{l}\text { Initial } \\
\text { (Chaotic) }\end{array}$ & Tactical & Defined & Managed & Optimising \\
\hline $\begin{array}{l}\text { Human } \\
\text { readable }\end{array}$ & No & Only & $\begin{array}{l}\text { Predominant } \\
\text { with some } \\
\text { machine- } \\
\text { processable } \\
\text { structure }\end{array}$ & $\begin{array}{l}\text { Detailed, } \\
\text { but detail } \\
\text { can obscure } \\
\text { meaning }\end{array}$ & $\begin{array}{l}\text { Presentation } \\
\text { tools take } \\
\text { account of } \\
\text { user } \\
\text { perspective } \\
\text { and purpose }\end{array}$ \\
\hline $\begin{array}{l}\text { Repeatable } \\
\text { by } \\
\text { automation }\end{array}$ & No & $\begin{array}{l}\text { There is } \\
\text { some chance } \\
\text { that } \\
\text { automated } \\
\text { sub- } \\
\text { processes } \\
\text { are } \\
\text { repeatable } \\
\text { with } \\
\text { considerable } \\
\text { investment } \\
\text { of effort }\end{array}$ & $\begin{array}{l}\text { Partially } \\
\text { automated } \\
\text { to the } \\
\text { extent that } \\
\text { the general } \\
\text { method can } \\
\text { be reapplied } \\
\text { for } \\
\text { (typically) } \\
\text { different } \\
\text { results }\end{array}$ & $\begin{array}{l}\text { Fully } \\
\text { automated, } \\
\text { repeatable } \\
\text { results is } \\
\text { possible in } \\
\text { some cases }\end{array}$ & $\begin{array}{l}\text { Processes } \\
\text { are auto- } \\
\text { matically } \\
\text { repeatable }\end{array}$ \\
\hline $\begin{array}{l}\text { Reusable, } \\
\text { that is, } \\
\text { repeatable } \\
\text { with im- } \\
\text { provement }\end{array}$ & Opaque & $\begin{array}{l}\text { There is } \\
\text { some chance } \\
\text { (decreasing } \\
\text { over time) } \\
\text { that sub- } \\
\text { processes } \\
\text { are } \\
\text { repeatable } \\
\text { with } \\
\text { considerable } \\
\text { investment } \\
\text { of effort }\end{array}$ & $\begin{array}{l}\text { Editing of } \\
\text { parameters } \\
\text { or selected } \\
\text { data for } \\
\text { rerun is } \\
\text { supported }\end{array}$ & $\begin{array}{l}\text { Processes } \\
\text { may be } \\
\text { arbitrarily } \\
\text { edited or } \\
\text { built upon } \\
\text { or varied for } \\
\text { improved } \\
\text { results }\end{array}$ & $\begin{array}{l}\text { Patterns in } \\
\text { provenance } \\
\text { are } \\
\text { discernible } \\
\text { and used for } \\
\text { process im- } \\
\text { provement }\end{array}$ \\
\hline Transparent & Opaque & $\begin{array}{l}\text { Only within } \\
\text { small } \\
\text { project } \\
\text { teams }\end{array}$ & $\begin{array}{l}\text { Formalised } \\
\text { approach to } \\
\text { trans- } \\
\text { parency } \\
\text { ensures that } \\
\text { some } \\
\text { decision } \\
\text { points are } \\
\text { noted and } \\
\text { justified }\end{array}$ & $\begin{array}{l}\text { Methods } \\
\text { and tools } \\
\text { are unam- } \\
\text { biguously } \\
\text { identified } \\
\text { but may not } \\
\text { be } \\
\text { interpretable } \\
\text { by } \\
\text { interested } \\
\text { parties }\end{array}$ & $\begin{array}{l}\text { Open access } \\
\text { to justified } \\
\text { methods } \\
\text { and tools for } \\
\text { all } \\
\text { nominated } \\
\text { parties; } \\
\text { explanatory } \\
\text { capability }\end{array}$ \\
\hline
\end{tabular}




\begin{tabular}{|c|c|c|c|c|c|}
\hline Capability & $\begin{array}{l}\text { Initial } \\
\text { (Chaotic) }\end{array}$ & Tactical & Defined & Managed & Optimising \\
\hline $\begin{array}{l}\text { Answerable } \\
\text { (variation in } \\
\text { results can } \\
\text { be } \\
\text { explained) }\end{array}$ & $\begin{array}{l}\text { Impossible } \\
\text { to say }\end{array}$ & $\begin{array}{l}\text { Some sub- } \\
\text { processes } \\
\text { may be } \\
\text { examined to } \\
\text { explain } \\
\text { variation } \\
\text { but } \\
\text { confidence is } \\
\text { low }\end{array}$ & $\begin{array}{l}\text { Variation } \\
\text { can be } \\
\text { attributed } \\
\text { to plausible } \\
\text { differences } \\
\text { based on } \\
\text { managed } \\
\text { time-stamps } \\
\text { or versions }\end{array}$ & $\begin{array}{l}\text { Failure to } \\
\text { reproduce } \\
\text { can be } \\
\text { diagnosed to } \\
\text { identifiably } \\
\text { different } \\
\text { components }\end{array}$ & $\begin{array}{l}\text { Automated; } \\
\text { diagnosis } \\
\text { limited only } \\
\text { by original } \\
\text { provenance } \\
\text { collection } \\
\text { granularity; } \\
\text { user } \\
\text { feedback } \\
\text { quality } \\
\text { included }\end{array}$ \\
\hline $\begin{array}{l}\text { Cross- } \\
\text { disciplinary } \\
\text { application }\end{array}$ & Unsuitable & $\begin{array}{l}\text { Relies on } \\
\text { serendipity }\end{array}$ & $\begin{array}{l}\text { Provenance } \\
\text { is available } \\
\text { in a } \\
\text { widely-used } \\
\text { format that } \\
\text { may be } \\
\text { partly } \\
\text { accessible to } \\
\text { multiple } \\
\text { discipline } \\
\text { areas; } \\
\text { generally } \\
\text { relies on a } \\
\text { lowest- } \\
\text { common- } \\
\text { denominator } \\
\text { approach }\end{array}$ & $\begin{array}{l}\text { Provenance } \\
\text { is made } \\
\text { available } \\
\text { through } \\
\text { multiple } \\
\text { portals or in } \\
\text { multiple } \\
\text { formats to } \\
\text { suit different } \\
\text { discipline } \\
\text { areas }\end{array}$ & $\begin{array}{l}\text { Provenance } \\
\text { management } \\
\text { works for } \\
\text { complex and } \\
\text { intractable } \\
\text { cross- } \\
\text { disciplinary } \\
\text { problems; } \\
\text { Inter- or } \\
\text { trans- } \\
\text { disciplinary } \\
\text { working is } \\
\text { deliberately } \\
\text { supported } \\
\text { through } \\
\text { management } \\
\text { of multiple } \\
\text { viewpoints }\end{array}$ \\
\hline
\end{tabular}

